БУТЬКО Т. В., д.т.н., професор,

ПРОХОРОВ В. М., к.т.н., асистент,

ЧЕХУНОВ Д. М., аспірант (Український державний університет залізничного транспорту)

\title{
Технологія інтелектуального управління сортувальною станцією на основі багатоцільової оптимізації з використанням генетичних алгоритмів
}

\begin{abstract}
Задача оперативного планування роботи сортувальної станиї в умовах обробки вагонопотоків із небезпечними вантажами має вирімуватись з одночасним урахуванням двох критеріїв: експлуатаційних витрат $i$ експозииї ризику. Вирішення управлінських задач такої складності можливе лише за умов застосування методів інтелектуального планування, оптимізаиї та прийняття рішень у складі індивідуально розробленої технологї інтелектуального управління. Для вирішення даної задачі таку технологію було створено. Вона зокрема використовує методи байєсових мереж для формалізацї ризиків, генетичні алгоритми спеціального типу як метод оптимізації, метод граничної корисності для звуження множини Парето та вироблення кінцевого рішення. Дана технологія є перспективною для вирішення $і$ інших багатокритеріальних задач, щуо виникають у транспортних системах і які одночасно є важкими для формалізації.

Ключові слова: сортувальна станція, технологія інтелектуального управління, вагони з небезпечними вантажами, багатокритеріальна оптимізація, генетичні алгоритми.
\end{abstract}

\begin{abstract}
Постановка проблеми
Найкращі технології планування, що базуються на класичній парадигмі управління, здатні головним чином лише на створення планів для досягнення певних задач із заздалегідь визначеними цілями у ситуаціях, коли відомі найбільш відповідні умови і коли на успіх плану не впливають зміни у зовнішньому оточенні [1]. Однак реальні задачі управління сучасними технічними і транспортними системами, які налічують велику кількість елементів і функціонують на межі своїх можливостей в умовах зовнішнього оточення, що постійно змінюється, кидають виклик цій класичній парадигмі, хоча вона, мабуть, його вже ніколи не зможе прийняти.

Задача планування оперативної роботи сортувальної станції (СC) в умовах обробки вагонопотоків із небезпечними вантажами (HB) $\epsilon$ прикладом такої задачі, вирішення якої в рамках класичної парадигми управління $\epsilon$ практично неможливим. Побудова такого плану $\epsilon$ складною комбінаторною задачею, для вирішення якої необхідно не лише сформувати оптимізаційну модель, але i повністю змоделювати весь технологічний процес, який зокрема включає перетворення потоків поїздів на потоки вагонів і знову на потоки поїздів із одночасним відгалуженням потоків місцевої роботи, взаємодію цих потоків 3 потоками обслуговування в умовах конкуренції 3 одночасною необхідністю виконання
\end{abstract}

() Т. В. Бутько, В. М. Прохоров, Д. М. Чехунов, 2018 строків та інших обмежень. Крім того, в умовах обробки вагонів 3 НВ оптимізаційна модель планування оперативної роботи СС має враховувати не лише критерій технологічних витрат, але й критерій мінімізації ризиків, що пов'язані із можливістю виникнення аварії та іiі наслідків, до яких зокрема належать загроза життю та здоров'ю персоналу станції та цивільному населенню, шкода навколишньому середовищу, технологічний збій у роботі СС та всієї транспортної системи тощо. Таким чином, дана задача $\epsilon$ також багатокритеріальною. Складність сучасних задач управління має одразу декілька аспектів, отже, вирішення таких комплексних задач на сучасному рівні вже $є$ неможливим без застосування інтелектуальних методів оптимізації, планування управління. Однак пройти всі етапи вирішення таких комплексних задач від аналізу даних до формалізації, оптимізації, вироблення і прийняття рішення в рамках єдиного методу є теж неможливим, навіть якщо цей метод $\epsilon$ сучасним. Для вирішення реальних управлінських задач, таких як задача планування оперативної роботи СС в умовах обробки вагонопотоків 3 HВ на сучасному рівні, необхідно розробити інтелектуальну технологію управління, яка буде визначати набір методів, послідовність і умови їх застосування для вирішення даної задачі.

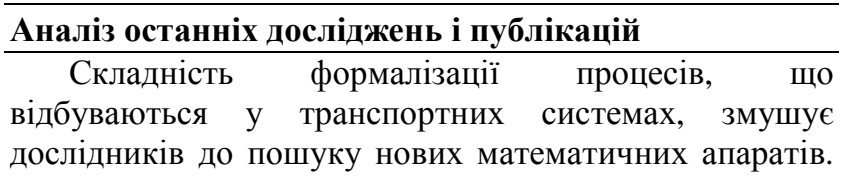


Так, у [2] запропоновано використання алгебри, основними операціями якої є сума Кронекера і добуток Кронекера. Такий підхід надасть можливість для математичного опису складних асинхронних процесів та процесів конкуренції за ресурси у транспортних підсистемах, зокрема i на СС. У [3] у пошуках лаконічної формалізації процесів на СС запропоновано використання теорії розкладу, а також доведено, що рівень складності цих процесів є набагато вищим, ніж процесів, які моделює ця теорія. У [4] запропоновано для формалізації процесів на СС і на станціях, на яких здійснюється перевантаження вантажів, використання графових структур. Ідеї використання технік штучного інтелекту і зокрема нейронних мереж для оптимізації процесів на СС запропонованобільше 20 років тому [5]. Але випадки, коли дослідники роблять крок від пропонування окремого методу штучного інтелекту для формалізації управлінських задач або оптимізації моделей до створення інтелектуальної технології управління складною технічною або транспортною системою, і досі поодинокі.

\section{Виділення не вирішених раніше частин загальної проблеми}

Незгасаючий інтерес до задачі оперативного планування роботи СС зокрема свідчить про те, що не лише не створено методу для ¥ї практичного вирішення, але не знайдено й сталого теоретичного базису для іï формулювання. Реальні умови, в яких задача оперативного управління роботою СС постає перед керівним персоналом залізниць, $€$ набагато складнішими, як, наприклад, необхідність керувати не лише технологічними витратами, але й ризиками при обробці вагонопотоків із НВ переводить цю задачу 3 класу однокритеріальних до класу багатокритеріальних задач. Така трансформація задачі значно звужує можливості для iіï формалізації і робить iii вирішення можливим лише за умови ретельного підбору методів та оформлення їх у вигляді технології інтелектуального управління.

\section{Формулювання цілей}

Метою дослідження $є$ створення технології інтелектуального управління оперативною роботою СС в умовах обробки вагонопотоків з НB, яка надасть можливість не лише формалізувати дану задачу у вигляді моделі, а потім іï оптимізувати, але й виробити кінцеве рішення зважаючи на багатокритеріальність даної задачі.

\section{Викладення основного матеріалу дослідження}

Як було зазначено у [5], для того щоб розроблений план оперативної роботи сортувальної станції (СС) при оперуванні вагонами 3 небезпечними вантажами (НВ) відповідав максимальному рівню безпеки, необхідно мінімізувати цільову функцію експозиції ризику:

$$
\mathrm{E}(x)=\sum_{t=1}^{T} \sum_{i=1}^{W} \sum_{j=1}^{N_{\Pi}} \sum_{k=1}^{N_{B}}\left(\xi_{i j} H\left(t-t_{j x}^{\Pi}\right) \cdot \varsigma_{i k} H\left(t_{k x}^{B}-t\right) \cdot \gamma Q_{i}(t) \cdot L_{i}\right)
$$

де $x$ - вектор керуючих змінних, який містить дані про порядок розгляду виконання операцій на $\mathrm{CC} ; W$ потужність множини вагонів, що розглядаються протягом планового періоду; $N_{\Pi}$ - потужність множини поїздів, що прибувають на станцію протягом планового періоду; $N_{B}$ - потужність множини поїздів, що відправляються зі станції протягом планового періоду; $\boldsymbol{\xi}_{i j}$ - функція, що набуває значення 1 , якщо $i$-й вагон прибув на станцію у складі $j$-го поїзда, або значення 0 в іншому випадку; $\zeta_{i k}-$ функція, що набуває значення 1 , якщо $i$-й вагон відправився зі станції у складі $k$-го поїзда, або значення 0 в іншому випадку; $t$ - поточне значення часу у хвилинах; $t_{j x}^{\Pi}-$ час прийняття на станцію $j$-го поїзда; $t_{k x}^{B}-$ час відправлення зі станції $k$-го поїзда; $Q_{i}(t)$ - поточне значення функції імовірності виникнення аварії з $i$-м вагоном, яке може бути отримане за допомогою моделі на основі байєсової мережі; $\gamma$ - коефіцієнт нормалізації ймовірностей; $T$ - часовий горизонт планування; $H$ - функція Гевісайда, яка визначена таким чином:

$$
H(z)= \begin{cases}0 & , z<0 \\ 1 & , z \geq 0\end{cases}
$$

Поточне значення функції імовірності виникнення аварії визначається за допомогою байєсової мережі [6]. Такий підхід надає можливість використовувати не лише статистичну інформацію, але й актуальну інформацію про безпосередній перебіг технологічних процесів та стан об'єктів на станції.

Однак первинною задачею оперативного планування роботи СС $є$ забезпечення виконання завдань на плановий період у повному обсязі при мінімальному рівні експлуатаційних витрат. 
Враховуючи те, що досягнення мінімуму експозиції ризику $\epsilon$ практично неможливим при одночасному досягненні мінімуму експлуатаційних витрат, тобто враховуючи наявність певного рівня конфлікту цих двох критеріїв, наступним кроком у вирішенні задачі автоматизації побудови плану оперативної роботи СС $\epsilon$ створення математичної моделі, яка б одночасно включала цільову функцію експозиції ризику та цільову функцію експлуатаційних витрат з подальшою їх сумісною мінімізацією засобами векторної оптимізації.

Сортувальна станція - складна система, у технологічний процес якої включені десятки операцій, що необхідні для забезпечення виконання планових обсягів робіт 3 розформування, формування та оброблення поїздів. Одними 3 найважливіших чинників, що впливають на процес планування, є технолого-економічні чинники. Тому цільову функцію, що відповідає критерію експлуатаційних витрат, можна зобразити в такому вигляді:

$$
\begin{aligned}
& C(x)=e_{\text {B.2 }}\left(\sum_{i=1}^{N_{\Pi}}\left(T-t_{i x}^{\Pi}\right) m_{i}^{\Pi}+\sum_{i=1}^{k} \sum_{j=1}^{q_{i}^{n p u \sigma}}\left(T-t_{i j}^{n p u \sigma}\right) m_{i j}-\sum_{i=1}^{N_{B}}\left(T-t_{i x}^{B}\right) m_{i}^{B}\right)+ \\
& +e_{\text {л’2 }}\left(\sum_{i=1}^{N_{\Pi Л}}\left(T-t_{i}^{\Pi Л}\right)+\sum_{i=1}^{N_{\Pi}}\left(T-t_{i x}^{\Pi}\right)-\sum_{i=1}^{N_{B}}\left(T-t_{i x}^{B}\right)-\sum_{i=1}^{N_{B Л}}\left(T-t_{i}^{B Л}\right)\right)+ \\
& +e_{n \cdot 2} \sum_{i=1}^{N_{\Pi}}\left(t_{i x}^{\Pi}-t_{i}^{n}\right)+e_{\pi \cdot 2} \sum_{i=1}^{k} \sum_{j=1}^{q_{i}^{n o d}}\left(2 a_{i}+b_{i} \cdot \min \left(m_{i j x}, m_{i}^{\max }\right)+\tau_{i}^{B i \partial u}\right)+ \\
& +e_{\pi \cdot 2} \sum_{i=1}^{K} \sum_{j=1}^{q_{i}^{n p u \sigma}}\left(2 a_{i}+b_{i} \cdot m_{i j}+\tau_{i}^{n p u ч}\right)+e_{n \cdot 2}\left(\sum_{i=1}^{N_{\Pi}}\left(t_{i x}^{n \kappa m o \Pi}-t_{i x}^{\Pi}\right)+\sum_{i=1}^{N_{B}}\left(t_{i x}^{B}-t_{i x}^{n \kappa m o B}\right)\right)
\end{aligned}
$$

де $e_{\text {6.г }}-$ вартість однієї вагоно-години; $t_{i x}^{\Pi}-$ момент часу приймання $i$-го поїзда до станції; $m_{i}^{\Pi}-$ кількість вагонів в $i$-му поїзді, що прибуває до станції; $t_{i x}^{B}-$ момент часу відправлення $i$-го поїзда зі станції; $m_{i}^{\Pi}-$ кількість вагонів в $i$-му поїзді із множини поїздів, що прибувають; $m_{i}^{B}-$ кількість вагонів у $i$-му поїзді із множини поїздів, що відправляються; $e_{\text {л:2 }}-$ вартість однієї локомотиво-години; $N_{\text {Пл }}-$ потужність множини локомотивів, що були спрямовані на сортувальну станцію в порядку виконання регулювальних заходів; $t_{i}^{\text {ПЛ }}$ - момент часу прибуття на станцію $i$-го локомотива в порядку виконання

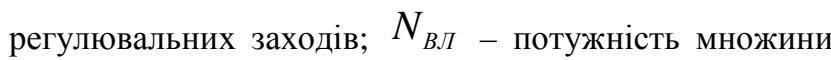
локомотивів, що були відправлені зі станції в порядку виконання регулювальних заходів; $t_{i}^{B Л}$ - момент часу відправлення зі станції $i$-го локомотива в порядку виконання регулювальних заходів; $e_{n \cdot 2}-$ вартість однієї поїздо-години; $t_{i}^{n}$ - час прибуття $i$-го поїзда до вхідного світлофора станції; $K$ - потужність множини під'їзих колій підприємств, що обслуговуються маневровими локомотивами станції; $q_{i}^{\text {nод }}$ - кількість подавань груп вагонів на вантажний фронт $i$-го підприємства у межах горизонту планування; $a_{i}-$ константа формули Фролова, яка відповідає базовій частині часу виконання напіврейсу подавання-прибирання вагонів на вантажний фронт $i$-го підприємства, яка залежить від довжини його під'їзої колії; $b_{i}$ - константа формули Фролова, яка відповідає частині часу виконання напіврейсу подавання-прибирання вагонів на вантажний фронт $i$-го підприємства, що залежить від довжини його під'їзної колії та кількості вагонів при подаванніприбиранні; $m_{i j x}$ - загальна кількість вагонів, що накопичені на виділеній колії станції для подавання на вантажний фронт $i$-го підприємства на момент початку $j$-ї подачі; $m_{i}^{\max }$ - максимально можлива кількість вагонів в подаванні на вантажний фронт $i$-го

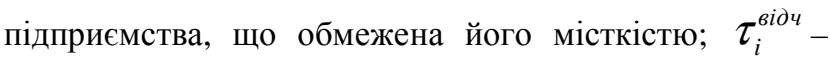
час, що витрачається на відчеплення групи вагонів при здійсненні подавання на вантажний фронт $i$-го підприємства; $q_{i}^{\text {приб }}-$ кількість прибирань груп 
вагонів із вантажного фронту $i$-го підприємства у межах горизонту планування; $m_{i j}$ - чисельність групи вагонів у $j$-му прибиранні із вантажного фронту $i$-го підприємства на момент для їх подальшої переробки на станції; $\tau_{i}^{\text {прич }}$ - час, що витрачається на причеплення групи вагонів при здійсненні їх прибирання із вантажного фронту $i$-го підприємства; $t_{i j}^{\text {приб }}$ - момент часу закінчення виконання операції $j$-го прибирання групи вагонів із вантажного фронту $i$-го підприємства; $t_{i x}^{n \kappa m o П ~-~ ч а с ~ п о ч а т к у ~ в и к о н а н н я ~}$ комплексного огляду $i$-го поїзда в парку прийняття; $t_{i x}^{n \kappa m o B}-$ час початку виконання комплексного огляду $i$-го поїзда в парку відправлення.

Крім того, на керуючі змінні, які входять до складу цільових функцій моделі, накладаються певні обмеження, що обумовлені технологічними особливостями процесу обробки поїздів. У ході комплексного огляду поїзда, що перебуває в парку відправлення, працівником вагонної служби, який входить до складу комплексної бригади, разом із членами локомотивної бригади здійснюється повне випробування пневматичних гальм. За результатами цієї операції видається довідка за формою ВУ-45. Простій такого поїзда в очікуванні нитки графіка після здійснення цієї операції не має перевищувати 30 хвилин. Цій умові відповідає обмеження:

$$
t_{i x}^{n \kappa m o B}+\tau_{i x}^{n \kappa m o B} \leq t_{i x}^{B}-30, \quad i=1 . . N_{B},
$$

де $t_{i x}^{n \kappa m o B}-$ час початку виконання комплексного огляду $i$-го поїзда в парку відправлення; $\tau_{i x}^{n \kappa m o B}-$ тривалість огляду $i$-го поїзда.

Крім того, план має бути коректним з точки зору збереження балансу локомотивів. Швидкість відправлення поїздів не має перевищувати швидкість прибуття локомотивів на станцію. Тобто для кожного моменту часу має виконуватись обмеження: кількість локомотивів, яка дорівнює кількості поїздів даного напрямку, що пройшли техогляд i очікують на відправлення, не має перевищувати кількості всіх наявних локомотивів для обслуговування даного напрямку. Цю наявну кількість можна обчислити як суму локомотивів, що прибули 3 поїздами даного напрямку до поточного моменту часу, і локомотивів, що прибули в порядку регулювальних заходів для обслуговування даного напрямку до поточного моменту часу, віднявши від неї кількість локомотивів, які на поточний момент часу були відправлені зі станції у складі поїздів даного напрямку. Дане обмеження має вигляд:

$$
n_{t}^{k O B} \leq \sum_{i=1}^{N_{\Pi}^{k}} H\left(t-t_{i x}^{\Pi}\right)+\sum_{i=1}^{N_{\Pi Л}^{k}} H\left(t-t_{i}^{\Pi J}\right)-\sum_{i=1}^{N_{B}^{k}} H\left(t-t_{i x}^{B}\right), \quad \forall k, t
$$

де $n_{t}^{k O B}$ - кількість локомотивів у складі поїздів $k$-го напрямку, які очікують нитки графіка в парку відправлення на момент часу $t ; N_{\Pi}^{k}-$ множина поїздів, що прибувають на станцію $3 k$-го напрямку; $N_{\text {Пл }}^{k}-$ множина локомотивів, що прибувають на станцію в порядку виконання регулювальних заходів для обслуговування поїздів $k$-го напрямку; $N_{B}^{k}-$ множина поїздів, що прибувають на станцію $3 k$-го напрямку; $t$ - поточний момент часу.

Оперативний план роботи СС має також давати змогу реалізувати таку послідовність і терміни виконання операцій, які забезпечать найшвидше відправлення вагонів, що містять вантажі зі спливаючим терміном доставки або вагонів з НВ. Ця вимога може бути виражена у вигляді обмеження: $t_{w j x}^{B}-t_{w i x}^{\Pi} \leq \tau_{\max }^{c n}, \quad w=1 . . P, j=1 . . n_{B}, \quad i=1 . . n_{\Pi}$,

де $t_{w j x}^{B}$ - момент часу відправлення $w$-го вагона, що належить до множини вагонів зі спливаючим терміном доставки або 3 HВ, у складі $j$-го поїзда зі станції; $t_{w i x}^{\Pi}-$ момент часу прибуття $w$-го вагона, що належить до множини вагонів зі спливаючим терміном доставки, у складі $i$-го поїзда до сортувальної станції; $\tau_{\max }^{c n}-$ нормативний максимальний час перебування вагонів зі спливаючим терміном доставки або з НВ на даній сортувальній станції; $P$ - потужність множини вагонів зі спливаючим терміном доставки або з НВ, що прибувають до сортувальної станції; $n_{B}$ - потужність множини поїздів, що відправляються зі станції; $n_{\Pi}$ 
потужність множини поїздів, що прибувають до станції.

При здійсненні подач вагонів на вантажні фронти підприємств, що з'єднані із сортувальною станцією під'їзними коліями, кількість вагонів у подачі визначається економічною доцільністю і може варіюватись, але вона не має перевищувати довжину вантажних фронтів:

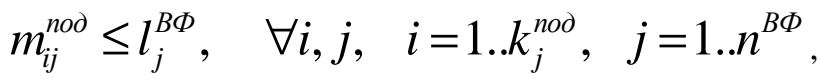

де $m_{i j}^{\text {под }}$ - кількість вагонів у $i$-му подаванні до $j$-го вантажного фронту; $l_{j}^{B \Phi}-$ довжина $j$-го вантажного фронту у вагонах; $k_{j}^{\text {под }}$ - кількість подавань до $j$-го вантажного фронту протягом планового періоду; $n^{B \Phi}-$ кількість вантажних фронтів.

Оперативний план роботи СС має містити такий порядок здійснення операцій з прибуття, формування i відправлення поїздів, який забезпечить наявність вільного місця на коліях накопичення на момент початку кожного розформування. Тобто сумарна місткість колій, які виділені під накопичення составів будь-якого напрямку, не має бути меншою, ніж кількість вагонів, які на ній вже перебувають, та кількість вагонів цього напрямку, які $є$ у поїзді, на момент початку його розформування, що можна сформулювати у вигляді обмеження:

$m_{i j}+\sum_{k=1}^{q_{j}} m_{k}^{\tau_{i}} \leq \sum_{k=1}^{q_{j}} l_{k j}, \quad \forall i, j, \quad i=1 . . N^{\Pi}, \quad j=1 . . n^{H \Phi}$ де $m_{i j}$ - кількість вагонів $j$-го напрямку у $i$-му поїзді, що надійшов у розформування; $q_{j}-$ кількість колій у сортувальному парку, які виділені для накопичення вагонів $j$-го напрямку; $m_{k}^{\tau_{i}}-$ кількість вагонів $j$-го напрямку, що перебувають на виділених коліях сортувального парку на момент початку

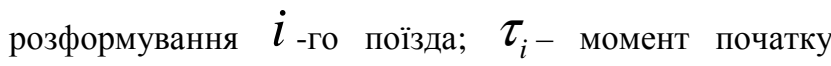
розформування $\boldsymbol{i}$-го поїзда; $l_{k j}$ - довжина $k$-ї колії, що виділена для накопичення вагонів $j$-го напрямку; $n^{H \Phi}$ - кількість напрямків, на які здійснюється формування составів.
Обов'язковим також $є$ виконання вимог, що їх висувають до складу сформованих поїздів Правила перевезень небезпечних вантажів. Наступне обмеження запобігає одночасній постановці до складу поїзда вагонів із вибуховими матеріалами та вагонів 3 вантажами, що належать до будь-якої із зазначених груп: небезпечні вантажі 1-го класу, сильнодіючі отруйні речовини, скраплені, стиснені або розчинені під тиском гази або пристрої, що їх містять:

$$
H\left(\sum_{j=1}^{n_{i}} \omega_{i j}^{B M}\right)+H\left(\sum_{j=1}^{n_{i}} \omega_{i j}^{K 1}+\sum_{j=1}^{n_{i}} \omega_{i j}^{C O}+\sum_{j=1}^{n_{i}} \omega_{i j}^{C T}\right) \leq 1, \quad \forall i, i \in N_{B}
$$

де $n_{i}$ - кількість вагонів $i$-го поїзда; $\omega_{i j}^{B M}$ - ознака $j$-го вагона у складі $i$-го поїзда, яка набуває значення 1, якщо вантаж вагона становлять вибухові матеріали, або 0 в іншому випадку; $\omega_{i j}^{K 1}-$ ознака $j$-го вагона у складі $i$-го поїзда, яка набуває значення 1, якщо у вагоні перевозяться небезпечні вантажі 1-го класу, в іншому випадку набуває значення $0 ; \omega_{i j}^{C O}-$ ознака $j$-го вагона у складі $i$-го поїзда, яка приймає значення 1, якщо у вагоні перевозяться небезпечні вантажі у вигляді сильнодіючих отруйних речовин, в іншому випадку набуває значення $0 ; \omega_{i j}^{C \Gamma}$ - ознака $j$ го вагона у складі $i$-го поїзда, який набуває значення 1, якщо у вагоні перевозяться небезпечні вантажі у вигляді скраплених, стиснених або розчинених під тиском газів та пристроїв, що їх містять, в іншому випадку набуває значення 0.

Значний інтерес у питанні вирішення складних оптимізаційних задач у багатоцільовій постановці становить науковий напрямок еволюційної багатоцільової оптимізації (англ. evolutionary multiobjective optimization, EMO), основу якого складають еволюційні алгоритми, які являють собою стохастичні оптимізаційні процедури, що імітують природні процеси еволюції, зокрема - Strength Pareto Evolutionary Algorithm (SPEA, SPEA-II), Pareto Envelope-Based Selection Algorithm (PESA, PESA-II) та ін.

Теоретично потужність множини Парето може бути дуже великою, в багатьох задачах ця множина може бути нескінченною. Тому будь-який алгоритм множини Парето-оптимальних рішень не гарантує знаходження всіх векторів цієї множини і навіть не має цього за мету. Переважна більшість алгоритмів еволюційної багатоцільової оптимізації реалізують концепцію відшукання найбільш якісної і репрезентативної вибірки множини Парето шляхом одночасного максимально можливого задоволення всіх цілей, які, крім того, можуть конкурувати між собою: 
максимальна близькість точок Парето до екстремумів усіх цільових функцій при одночасній максимальній їх диверсифікації. Під диверсифікацією слід розуміти максимізацію відмінності між двома окремими точками Парето фронту, яку можна представити як максимізацію відстані між ними.

До алгоритмів еволюційної багатоцільової оптимізації, які реалізують цю концепцію, найбільш успішно належать алгоритми, які з усіх природних процесів еволюції роблять основний акцент на генетичних операціях - генетичні алгоритми (англ. Genetic algorithms, GA).

Для вирішення багатоцільових оптимізаційних задач необхідне використання спеціалізованих генетичних алгоритмів, які розроблені спеціально для відшукання векторів множини Парето. До таких спеціалізованих алгоритмів, які демонструють найкращі результати, в першу чергу можна віднести генетичний алгоритм недомінованого ранжування 3 використанням механізму елітизму NSGA-II (англ. Fast elitist non-dominated sorting genetic algorithm) [7]. Етапи виконання алгоритму подано на рис. 1 .

3 двох популяцій перевага віддається тій, яка має менший недомінований ранг. Якщо обидві популяції належать до одного фронту, то перевага віддається тій, яка має більшу відстань скупчення.

На основі створених моделей було розроблено програмне забезпечення у середовищі Matlab. Результати моделювання у вигляді множини точок Парето-фронту наведено на рис. 2.

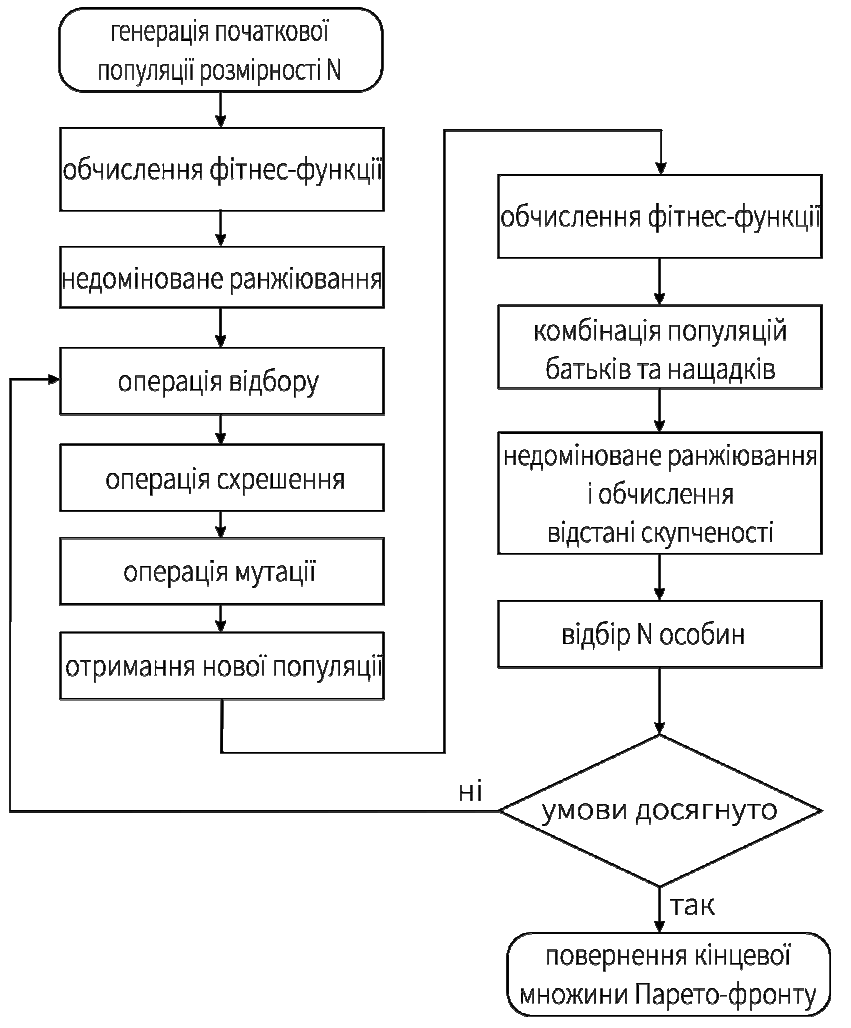

Рис. 1. Етапи реалізації спеціального генетичного алгоритму NSGA-II

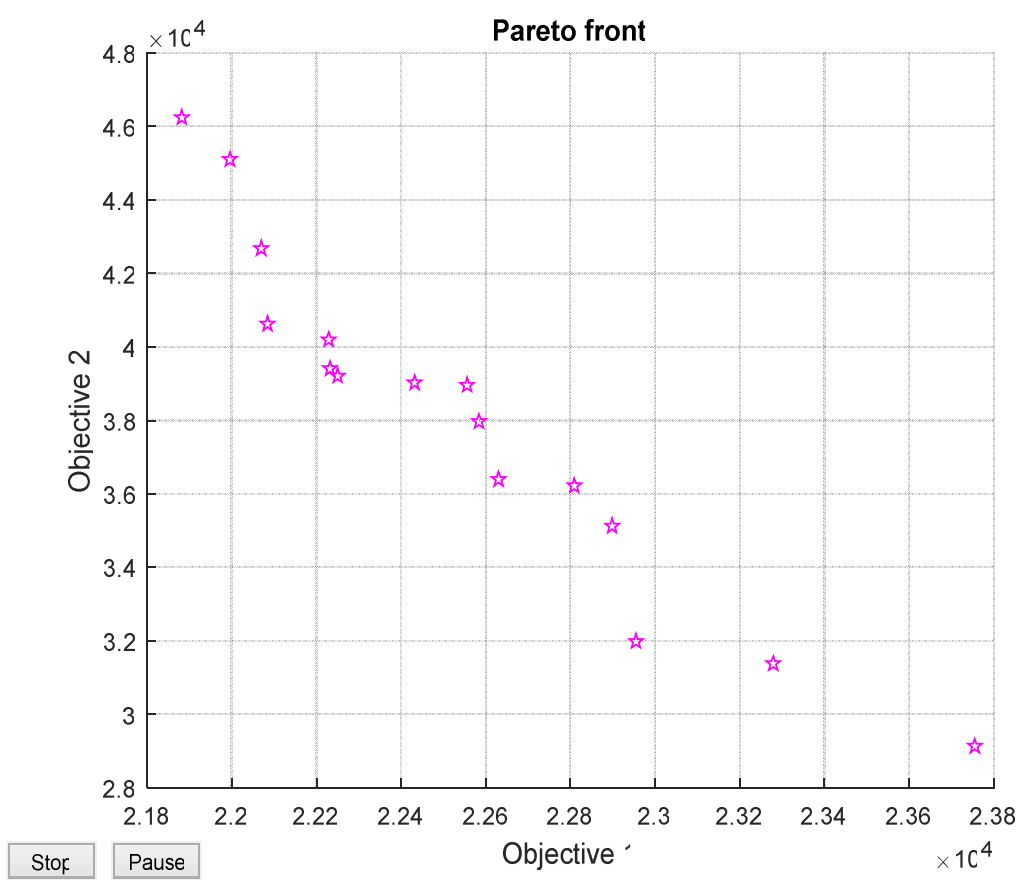

Рис. 2. Множина цільових векторів, що відповідають множині Парето-оптимальних рішень, отриманих у результаті оптимізації розробленої моделі з використанням генетичного алгоритму NSGA-II 
Наступним кроком після здійснення оптимізації і отримання множини Парето-оптимальних рішень $є$ прийняття кінцевого рішення. Для вибору єдиного рішення із множини рішень, які є оптимальними, за Парето існують декілька десятків методів, однак майже всі вони мають певні недоліки. Основним недоліком багатьох 3 цих методів $\epsilon$ те, що для звуження множини Парето вони потребують наявності додаткової інформації. Переважна більшість методів, такі як, наприклад, метод прийняття рішень на основі аналізу ієрархій (англ. АНР, Analytic hierarchy process) та метод прийняття рішень на основі аналізу мереж (англ. ANP, Analytic network process) [8], потребують створення людиною-експертом таблиці попарного порівняння альтернативних векторів рішень із множини Парето. Крім того, для визначення єдиного рішення при потужності множини Парето більше ніж 5-7 елементів ці методи також потребують проведення значних обсягів обчислень. Актуальність питань формалізації та автоматизації процесів прийняття рішень, а також складнощі, які виникають при застосуванні існуючих методів прийняття рішень при вирішенні багатокритеріальних задач, $€$ однією 3 причин виникнення нових методів. Наприклад, новий метод найкращого і найгіршого критерію (англ. BWM, Best worst method) [9], який було створено 2015 року, не потребує попарного порівняння альтернативних рішень, однак все одно потребує втручання людиниексперта для ранжування критеріїв від найбільш важливого до найменш важливого за бальною шкалою. Однак така потреба у зовнішньому втручанні i використанні суб'єктивної інформації не лише ускладнює формалізацію процесу прийняття рішень та застосування методів прийняття рішень, але призводить до того, що значна кількість методів потерпає від впливу так званого фундаментального парадоксу теорії прийняття рішень на основі багатьох критеріїв [10], суть якого полягає в тому, що при застосуванні різних методів при вирішенні однієї і тієї самої задачі можна отримати неоднакові рішення. До методів, які відчувають вплив цього парадоксу, належать і ті ж методи на основі аналізу ієрархій та аналізу мереж, i популярні методи, що використовують моделі на основі зваженого добутку та зваженої суми (адитивної згортки) [11].

Однак існують методи прийняття рішень 3 урахуванням багатьох критеріїв, які вільні від впливу зазначеного парадоксу, не потребують додаткової інформації та складних обчислень. Метод граничної корисності (англ. MUM, Marginal utility method) [12] визначає оптимальне рішення на основі виявлення найменшої величини спорідненості між найближчими векторами у просторі значень цільових векторів. Для визначення кінцевого рішення двокритеріальної оптимізаційної задачі, якою $\epsilon$ задача побудови раціонального плану оперативної роботи СС в умовах обробки вагонопотоків із НВ, необхідно провести аналіз усіх векторів у цільовому просторі на предмет ступеня їх спорідненості із двома найближчими сусідніми векторами рішень. Розглянемо довільний вектор $V^{0}$, що належить до множини Паретооптимальних недомінованих векторів рішень i координатами якого $є$ значення цільових функцій $\overline{\left(f_{1}^{0}, f_{2}^{0}\right)}$. По-перше, необхідно визначити два найближчі сусідні вектори $V^{1}$ та $V^{2}$ з координатами $\overline{\left(f_{1}^{1}, f_{2}^{1}\right)}$ та $\overline{\left(f_{1}^{2}, f_{2}^{2}\right)}$ такими, що $\left(f_{1}^{1} \leq f_{1}^{0} \leq f_{1}^{2}\right)$ та $\left(f_{2}^{1} \geq f_{2}^{0} \geq f_{2}^{2}\right)$. Ці вектори визначають як ті, що найменш віддалені від центроїдів із $k$ найближчих векторів, перша координата яких є спочатку меншою, а потім більшою за $f_{1}^{0}$. Після визначення цих векторів для кожного вектора $V^{0}$ визначається його функція спорідненості:

$$
A_{V^{0}}=\max \left(\frac{f_{0}^{1}-f_{1}^{1}}{f_{1}^{2}-f_{0}^{2}}, \frac{f_{2}^{1}-f_{0}^{1}}{f_{0}^{2}-f_{2}^{2}}\right) .
$$

Значення функції спорідненості визначається для всіх векторів, однак для $k$ крайніх векторів на обох кінцях Парето-фронту вона може не визначатись тому, що вважається, що для цих векторів вона апріорі $\epsilon$ найменшою. Величина $k$ представляє роздільну здатність, з якою обчислюється функція спорідненості та визначається компромісне рішення. Вона може прийматись залежно від потужності множини Парето або виходячи 3 інших міркувань. У даному дослідженні величину $k$ прийнято рівною 2 . Оптимальним компромісним рішенням за методом граничної корисності $€$ рішення, якому відповідає цільовий вектор 3 мінімальним значенням функції спорідненості. Дані розрахунків зведено у табл. 1.

Таким чином, за даними розрахунків функція спорідненості набуває значення 0,0756 для вектора під номером 11, це значення $є$ мінімальним серед усіх точок Парето-фронту. Отже, вектор № 11 із значенням цільової функції експлуатаційних витрат $C(x)$ у 22630,52 грн і значенням цільової функції експозиції ризику $\mathscr{E}(x)$ у 36394,43 грн приймається як кінцеве компромісне рішення.

Рис. 3 відображає розташування точки рішення відносно решти точок Парето-фронту та його особливих точок, таких як ідеальна точка, точка надир та якірні точки. 
Таблиця 1

Дані розрахунків щодо вибору компромісного рішення із множини Парето-оптимальних рішень двокритеріальної оптимізаційної задачі за методом граничної корисності

\begin{tabular}{|c|c|c|c|c|c|c|c|c|c|}
\hline $\begin{array}{c}\text { № } \\
\text { вект. }\end{array}$ & $f_{1}^{0}$ & $f_{2}^{0}$ & $f_{1}^{1}$ & $f_{2}^{1}$ & $f_{1}^{2}$ & $f_{2}^{2}$ & $\frac{f_{0}^{1}-f_{1}^{1}}{f_{1}^{2}-f_{0}^{2}}$ & $\frac{f_{2}^{1}-f_{0}^{1}}{f_{0}^{2}-f_{2}^{2}}$ & $A_{V^{0}}$ \\
\hline 1 & 21882,15 & 46244,54 & - & - & - & - & - & - & - \\
\hline 2 & 21995,83 & 45099,36 & - & - & - & - & - & - & - \\
\hline 3 & 22069,60 & 42676,98 & - & - & - & - & - & - & - \\
\hline 4 & 22084,57 & 40622,97 & 21882,15 & 46244,54 & 22250,21 & 39208,43 & 0,0360 & 0,1171 & 0,1171 \\
\hline 5 & 22228,97 & 40196,36 & 21995,83 & 45099,36 & 22431,90 & 39022,44 & 0,0476 & 0,1729 & 0,1729 \\
\hline 6 & 22232,13 & 39408,29 & 22069,60 & 42676,98 & 22556,16 & 38958,21 & 0,0497 & 0,7199 & 0,7199 \\
\hline 7 & 22250,21 & 39208,43 & 22084,57 & 40622,97 & 22584,19 & 37964,67 & 0,1171 & 0,2685 & 0,2685 \\
\hline 8 & 22431,90 & 39022,44 & 22228,97 & 40196,36 & 22630,52 & 36394,43 & 0,1729 & 0,0756 & 0,1729 \\
\hline 9 & 22556,16 & 38958,21 & 22232,13 & 39408,29 & 22809,24 & 36218,46 & 0,7199 & 0,0924 & 0,7199 \\
\hline 10 & 22584,19 & 37964,67 & 22250,21 & 39208,43 & 22898,81 & 35123,08 & 0,2685 & 0,1107 & 0,2685 \\
\hline 11 & 22630,52 & 36394,43 & 22431,90 & 39022,44 & 22954,93 & 31986,50 & 0,0756 & 0,0736 & 0,0756 \\
\hline 12 & 22809,24 & 36218,46 & 22556,16 & 38958,21 & 23279,22 & 31374,85 & 0,0924 & 0,0970 & 0,0970 \\
\hline 13 & 22898,81 & 35123,08 & 22584,19 & 37964,67 & 23755,44 & 29131,25 & 0,1107 & 0,1430 & 0,1430 \\
\hline 14 & 22954,93 & 31986,50 & - & - & - & - & - & - & - \\
\hline 15 & 23279,22 & 31374,85 & - & - & - & - & - & - & - \\
\hline 16 & 23755,44 & 29131,25 & - & - & - & - & - & - & - \\
\hline
\end{tabular}

На рис. 4 наведено тривимірну криву, що демонструє залежність значень адитивної згортки на основі цільових функцій $C(x)$ та $\mathscr{E}(x)$ від значень, яких набувають ці цільові функції в точках Парето-фронту.

Виходячи із технології роботи СС та формулювань даних цільових функцій можна стверджувати, що визначити загальний характер їх взаємозалежності на всій області їх визначення, що відповідає простору допустимих рішень, наприклад у вигляді аналітичної функції регресії, є неможливим. Ця взаємозалежність $є$ складною і неоднозначною. По-перше, комбінаторний характер даної оптимізаційної задачі виключає можливість наявності гладких цільових функцій. А подруге, їх характер взаємодії не можна вважати повністю конкурентним. Наприклад, зменшення простою вагонів із НВ у сортувальному парку станції призведе до зменшення експозиції ризику, однак разом 3 цим одночасно зменшиться i загальний простій вагонів, що приведе і до зменшення експлуатаційних витрат. 


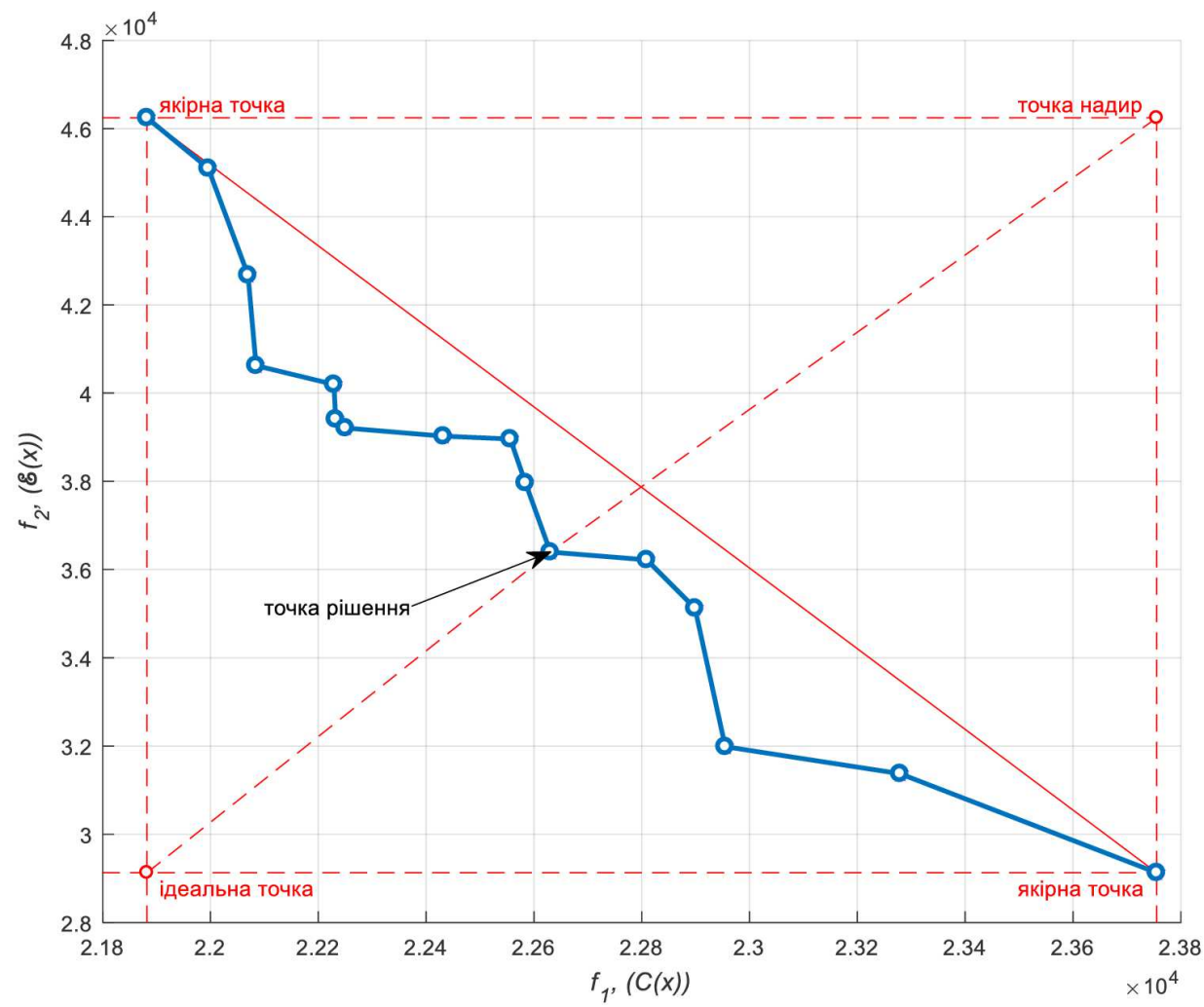

Рис. 3. Точка компромісного рішення задачі планування оперативної роботи СС, точки недомінованих рішень Парето-фронту, ідеальна точка, точка надир та якірні точки

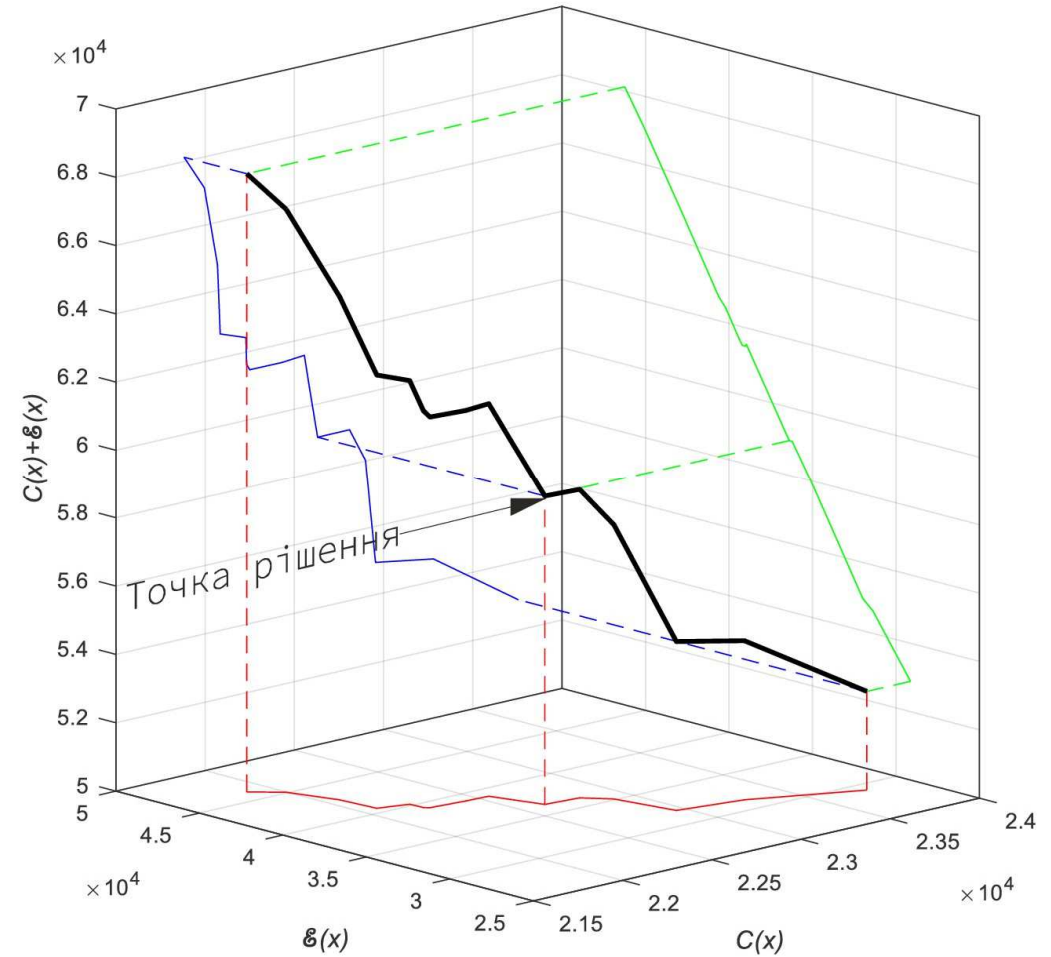

Рис. 4. Залежність значень адитивної згортки на основі цільових функцій $C(x)$ та $\mathscr{E}(x)$ від значень, яких набувають цільові функції в точках Парето-фронту 
Однак, крива залежності, що подано на рис. 4, доводить, що при вирішенні даної оптимізаційної задачі із вихідними даними, що відповідають ступеню завантаження станції, який є близьким до максимально можливого, в зоні максимальної оптимізації, що відповідає множині Парето, взаємодія цільових функцій $C(x)$ та $\mathscr{E}(x)$ відбувається в режимі жорсткої конкуренції. Проекція кривої на площину В демонструє близьку до прямої лінію залежності значення адитивної згортки від значення функції $\mathscr{E}(x)$, тобто із зростанням функції $\mathscr{E}(x)$ монотонно зростає i функція згортки, тобто різкі коливання значень функції $C(x) \quad$ згладжуються компенсуючими коливаннями функції $\mathscr{E}(x)$. Тобто в режимі максимально можливої оптимізації роботи станції, яка до того ж працює близько до межі максимального навантаження, покращення одного критерію можливо досягнути лише за рахунок погіршення іншого критерію.

Рисунок також демонструє, що зменшення значень адитивної згортки в зоні Парето-фронту відбувається також лише при одночасному збільшенні значень функцій $C(x)$. Про це свідчить також і мінімум адитивної згортки, який припадає на другу якірну точку Парето-фронту. Однак даний вектор обирати як кінцеве рішення недоцільно, тому що він відповідає локальному максимуму технологічних витрат. А тому саме вектор $11 €$ раціональним компромісним рішенням, що і було доведено в результаті проведення розрахунків.

\section{Висновки \\ Аналіз отриманого у результаті моделювання рішення довів ефективність розробленої технології інтелектуального управління. Дану технологію було спеціально розроблено для вирішення задачі оперативного управління роботою сортувальної станції в умовах обробки вагонопотоків, що містять вагони із небезпечними вантажами. Вона дає змогу не лише формалізувати складні технологічні процеси, але i оптимізувати модель за принципами багатоцільової оптимізації, а також виробити єдине компромісне рішення. Застосування універсальних, гнучких i потужних механізмів, таких як генетичні алгоритми, робить дану технологію перспективною для застосування при вирішенні i iнших багатокритеріальних задач, що виникають у транспортних системах і які одночасно є важкими для формалізації.}

\section{Список використаних джерел}

1. Yang, Q. Intelligent planning: A decomposition and abstraction based approach [Text] / Q. Yang // Springer, Berlin, 1997.
2. Volcic, M. Kronecker algebra and its broad applications in railway systems. [Text] / M. Volcic, J. Blieberger, A. Schöbel. In EURO-ŽEL 2013. Recent Challenges for European Railways, 2013. P. 275-282.

3. Guo, R. Optimizing model of A railroad yard's operations plan based on production scheduling theory [Text] / R. Guo, J. Guo, G. Xie // Computers in Railways XV: WIT Transactions on The Built Environment, WIT Press, 2016. - Vol. 162. P. 79-90

4. Boysen, N. Scheduling freight trains in rail-rail transshipment yards [Text] / N. Boysen, F. Jaehn, E. Pesch // Transportation science, 2011. Vol. 45, No. 2. - P. 199-211.

5. Florio, L. Railway station planning using artificial intelligence techniques [Text] / L. Florio, L. Mussone. // Transactions on the Built Environment. - Vol. 18, 1996. - P. 203-212.

6. Чехунов, Д. М. Формування моделі оцінки ризиків на сортувальній станції при оперуванні вагонами 3 небезпечними вантажами із використанням математичних апаратів нечіткої логіки та байєсових мереж [Текст] / Д. М. Чехунов // IКСЗТ. - 2018. №1. - C. 35-41.

7. Srinivas, N.. Multiobjective optimization using nondominated sorting in genetic algorithms [Text] / N. Srinivas, D. Kalyanmoy // Evolutionary Computation, - 1994. - Vol. 2(3). - P. 221 - 248.

8. Saaty, T. Relative Measurement and its generalization in decision making: why pairwise comparisons are central in mathematics for the measurement of intangible factors [Text] / T. Saaty //- Physical and natural sciences, Series A: Mathematics - 2008. 102 (2). - P. 251-318. doi:10.1007/bf03191825.

9. Rezaei, J. Best-worst multi-criteria decision-making method. [Text] / J. Rezaei // Omega - 2015. - Vol. 53. - P. 49-57.

10. Triantaphyllou, E. An examination of the effectiveness of multi-dimensional decision-making methods: a decision-making paradox [Text] / E. Triantaphyllou; S. Mann // International Journal of Decision Support Systems - 1989. (5). - P. 303-312. doi:10.1016/0167-9236(89)90037-7.

11. Tofallis, C. Add or multiply? A tutorial on ranking and choosing with multiple criteria [Text] / C. Tofallis // INFORMS Transactions on education. - 2014. Vol. 14(3). - P. 109-119.

12. Zhao J. Optimization of part-building orientation for rapid prototyping manufacturing. [Text] / J. Zhao, L. He, W. Liu, H. Bian // Journal of computer-aided design and computer graphics. - 2006. - Vol. 18(3). P. 456-463. 
Butko T. V., Prokhorov V. M., Chekhunov D. M. The technology of intelligent control of the switchyard station on the basis of multi-objective optimization using genetic algorithms. The task of operational planning of the marshalling yard in the conditions of handling carloads with dangerous goods should be solved with simultaneous consideration of two criteria: operational costs and exposure to risk. The solution to this problem is practically impossible within the framework of the classical control paradigm. The solution of management tasks of such complexity is possible only if intelligent planning methods, optimization and decisionmaking are applied as part of individually developed intelligent management technology. To solve this problem, such a technology was created, in particular it uses Bayesian methods for formalizing risks, genetic algorithms of a special type as an optimization method, a marginal utility method for narrowing the Pareto set and developing a final solution. The developed technology was implemented as a software in Matlab environment and modeling was carried out. As shown by the modeling, this technology is promising for solving multicriteria problems arising in transport systems and at the same time difficult for formalization.

Keywords: marshalling yard, technology of intelligent control, cars with dangerous goods, multicriteria optimization, genetic algorithms.

Бутько Т. В., Прохоров В. Н., Чехунов Д. Н. Технология интеллектуального управления сортировочной станцией на основе многоцелевой оптимизации с использованием генетических алгоритмов. Задача оперативного планирования работы сортировочной станции в условиях обработки вагонопотоков с опасными грузами должна решаться с одновременным учетом двух критериев: эксплуатационных расходов и экспозиции риска. Решение управленческих задач такой сложности возможно лишь при условии применения методов интеллектуального планирования, оптимизации и принятия решений в составе индивидуально разработанной технологии интеллектуального управления. Для решения данной задачи такая технология была создана, она в частности использует методы байесовской сети для формализации рисков, генетические алгоритмы специального типа в качестве метода оптимизации, метод предельной полезности для сужения множества Парето и выработки окончательного решения. Данная технология является перспективной для решения и других многокритериальных задач, возникающих в транспортных системах и одновременно являются трудными для формализации.
Ключевые слова: сортировочная станция, технология интеллектуального управления, вагоны с опасными грузами, многокритериальная оптимизация, генетические алгоритмы.

Надійшла 18.06.2018 p.

Butko Tetiana Vasylivna, Dr.Sc., professor, chief of department, department of Management of operational work, Ukrainian State University of Railway Transport, Kharkiv, Ukraine.E-mail: butko@kart.edu.ua ID ORCID 0000-0003-1082-599X

Prokhorov Victor Mykolaiovych, Ph.D., department of Management of operational work, Ukrainian State University of Railway Transport, Kharkiv, Ukraine. E-mail: prokhorov@kart.edu.ua ID ORCID 0000-00018963-6467

Chekhunov Denys Mykolaiovych, post graduate, department of Management of operational work, Ukrainian State University of Railway Transport, Kharkiv, Ukraine. E-mail: uermp@ukr.net ID ORCID 0000-0002-1570-6351

Бутько Тетяна Василівна, д.т.н., професор, завідувач кафедри, кафедра управління експлуатаційною роботою, Украйнський державний університет залізничного трансnорту. E-mail: butko@kart.edu.иa ID ORCID 0000-0003-1082-599X

Прохоров Віктор Миколайович, к.т.н., кафедра управління експлуатаційною роботою, Украӥнський державний університет залізничного транспорту. E-mail: prokhorov@kart.edu.ua ID ORCID 0000-00018963-6467

Чехунов Денис Миколайович, аспірант, кафедра управління експлуатаційною роботою, Украӥнський державний університет залізничного транспорту. E-mail: uermp@ukr.net ID ORCID 0000-0002-15706351 